\title{
The Effect of Tractor Speed and Canopy Position on Fungicide Spray Deposition and Peach Scab Incidence and Severity
}

\author{
Clive H. Bock, ${ }^{1, \dagger}$ Glen C. Rains, ${ }^{2, \dagger}$ Mike W. Hotchkiss, ${ }^{1}$ Chunxian Chen, ${ }^{1}$ and Phil M. Brannen ${ }^{3}$ \\ ${ }^{1}$ USDA-ARS-SEFNTRL, Byron, GA 31008 \\ ${ }^{2}$ University of Georgia, Tifton, GA 31793 \\ ${ }^{3}$ University of Georgia, Athens, GA 30602
}

Abstract

\begin{abstract}
Peach scab, caused by Venturia carpophila, is a damaging disease of peach in the southeastern United States. Thus, fungicides are applied to reduce peach scab. Tractor speed was investigated as a variable affecting spray deposition and disease control in relation to volume applied. In experiments in 2015 and 2016, trees were sprayed with fungicide to control scab at petal fall to $1 \%$ shuck split and at shuck split to $10 \%$ shuck off. Speeds were 3.2, 4.8, and $6.4 \mathrm{kph}$ resulting in 1,403, 935, and 701 liters/ ha, respectively, with the dose of active ingredient (a.i.) per ha kept constant. Deposition declined for all speeds with later spray dates. There was a negative linear relationship between tractor speed and spray coverage on three of four dates the experiment was repeated. Tractor speed (different volumes, equal doses) affected peach scab. In 2015 and 2016, mean
\end{abstract}

incidence at 3.2, 4.8, and $6.4 \mathrm{kph}$ was $68.6,59.2$, and $38.3 \%$, and 64.2 , 53.0 , and $40.4 \%$ of fruit scabbed, respectively. Effect of speed on lesion number per fruit depended on year: in 2015 , lesions per fruit were reduced at $6.4 \mathrm{kph}$ compared with 3.2 and $4.8 \mathrm{kph}$ but were not different in 2016. Control trees had fewer lesions per fruit high in the canopy, but there was little effect of sample height in fungicide-treated trees. Concentration of a.i. in lower volumes applied at higher speed may provide some benefit in reducing incidence of peach scab, but there appeared to be less effect on severity.

Keywords: fungi, integrated management, epidemiology, fungicide, fruit crops
Peach scab, caused by the fungal pathogen Venturia carpophila E.E. Fisher (syn. Fusicladosporium carpophilum Partridge and Morgan Jones; Cladosporium carpophilum Thüm.; Megacladosporium carpophilum Thüm. (Vienn.-Bourg); Fusicladium carpophilum Thüm (Oudem.); Cladosporium americanum H.C. Greene) is a major disease of peach (Prunus persica (L.) Batsch) in the wet, humid environments of the southeastern United States (Keitt 1917; Scherm and Brannen 2005). The pathogen infects fruit, twigs, and leaves of peach trees. When fruit infection occurs, scab lesions on the surface can make the fruit unsuitable for the fresh market, and in extreme cases can cause cracking of the fruit and premature fruit drop (Keitt 1917; Scherm and Brannen 2005). The appearance of fruit with lesions is less appealing to consumers, resulting in symptomatic fruit being culled to a lower grade or removed from the packing line entirely (Anonymous 2004), which incurs an economic loss for the

${ }^{\dagger}$ Corresponding authors: C. H. Bock, clive.bock@ars.usda.gov; G. C. Rains, grains@uga.edu

Authors C. H. Bock and G. C. Rains contributed equally to this work.

This article reports the results of research only. Mention of a trademark or proprietary product is solely for the purpose of providing specific information and does not constitute a guarantee or warranty of the product by the U.S. Department of Agriculture and does not imply its approval to the exclusion of other products that may also be suitable.

Funding: The research was supported by USDA-ARS through CRIS project 6606-21000-004-00D and 6606-21220-011-00D.

*The $\boldsymbol{e}$-Xtra logo stands for "electronic extra" and indicates there are supplementary materials published online.

The author(s) declare no conflict of interest.

Accepted for publication 14 February 2020.

This article is in the public domain and not copyrightable. It may be freely reprinted with customary crediting of the source. The American Phytopathological Society, 2020. grower. Furthermore, colonization of scabbed peach fruit by other pathogens gaining access through scab-induced cracking of the fruit surface can also occur (Keitt 1917), and these may act as a source of rot for adjacent, otherwise healthy peaches.

The life cycle of the scab pathogen on peach is driven by rain events. During spring and early summer, conidia of $V$. carpophila are splash dispersed from overwintering twig infections by rain (Keitt 1917; Lan and Scherm 2003; Lawrence and Zehr 1982; Scherm et al. 2008). In central Georgia, fruit set occurs in March, and as a result, the peak in conidia production occurs from mid-March to late-June (Scherm et al. 2008). Peach fruit are exposed to conidia of V. carpophila from very early stages in their development, the first exponential growth phase being characterized as S1 (Lombardo et al. 2011). The disease has a prolonged latent period of approximately 42 days for lesions to fully develop prior to harvest (Keitt 1917; Scherm and Brannen 2005). Fruit surface moisture from rain or dew allows conidia to germinate and infect fruit. Symptoms appear as small, dark lesions scattered across the surface of fruit and occur frequently on fruit surfaces facing upward at the time of early fruit development (Bock et al. 2011).

Fungicide spray programs are recommended for the control of peach scab. Relatively recently, reduced-fungicide strategies have been developed as effective, reasonably economical, and lower environmental impact alternatives to older strategies (Lan et al. 2003; Scherm and Brannen 2005; Scherm and Savelle 2001; Schnabel and Layne 2004; Schnabel et al. 2007). The two most critical fungicide applications for control of peach scab are applied at petal fall to $1 \%$ shuck split and at shuck split to $10 \%$ shuck off (Blaauw et al. 2019).

Fungicide spray programs are most often applied using a small orchard airblast sprayer (Reilly et al. 2004). The deposition achieved using handgun sprayers, airblast with different airflow rates, and air-assisted rotary atomizer sprayers have been compared variously in different studies (Chiba 1974; Reichard et al. 1979; Reilly et al. 2004). Reilly et al. (2004) found no detectable difference in deposition between airblast and air-assisted rotary sprayer applications, although there was a lower incidence of peach scab using an airblast sprayer compared with an air-assisted rotary atomizer in two of the four seasons the experiment was conducted. Yates et al. (1974) 
compared airblast and helicopter application at different speeds and volumes. Results indicated that the airblast sprayer (a Spray Master BD264, distributed by Hart-Carter Pacific Corp., San Jose, CA) operated at $3.22 \mathrm{kph}$ and delivering 175 liters/ha resulted in greatest deposition - but applied at substantially less volume than contemporary airblast sprayers typically apply to peach trees. Airblast sprayers use an axial fan to generate high-velocity air that leaves the cowling and entrains the droplets from the sprayer nozzles, directing them toward the target tree (Fox et al. 2008). The effective distance to which spray can be transported is likely to be affected by the velocity of the air at different distances from the fan outlet, which has been shown to decline rapidly with distance from the fan outlet (Bock et al. 2015; Fox et al. 1992). The use of airblast sprayers has been studied in other orchard crops including apples, citrus, pecans, and in vineyards (Banaj et al. 2010; Bock et al. 2015; Celen et al. 2008; Herrington et al. 1981; Holownicki et al. 2000; Pergher 2004; Randall 1971; Reilly et al. 2007; Salyani and Hoffmann 1996; Travis et al. 1987a, b), but as indicated above, only a few studies have been done in peach orchards (Chiba 1974; Marucco et al. 2008; Reilly et al. 2004). Apart from prevailing weather conditions, various factors can impact coverage and deposition in orchard crops including canopy density (Herrington et al. 1981; Travis et al. 1987a). Other factors that affect deposition include tree height (Bock et al. 2015; Reilly et al. 2007), air velocity of the fan, forward speed and volume of application (Marucco et al. 2008; Travis et al. 1987b), nozzle arrangement and selection (Travis et al. 1987b), and air volume and pressure (Randall 1971). Marucco et al. (2008) indicated that a forward velocity of $7 \mathrm{kph}$ and an air velocity of $14 \mathrm{~m} / \mathrm{s}$ provided most uniform deposition at low volumes (up to 400 liters/ha). However, results from deposition studies have rarely been directly related to disease control, the purpose of fungicide application. There are examples where treerow volume has been used in some orchard crops to optimize application parameters in relation to disease control, including in apple and citrus orchards (Scapin et al. 2015; Sutton and Unrath 1984, 1988). For peach orchards, generally predetermined spray volumes are applied regardless of age, tree size, or planting density, despite guidelines for tree row volumes having been developed for stone fruit, including peach orchards (Rüegg and Viret 1999). Impacts of volume, speed, and dose (= rate) of active ingredient (a.i.) for controlling peach scab and other peach diseases remains uncharacterized.

In a review on the effects of pesticide volume and dose on pest and disease control, Barber and Landers (2002) found that most often, improved control was achieved using lower volumes of spray per hectare, implying that dose is a critical function of pesticide efficacy. However, Barber and Landers (2002) did note the influences of pesticide mode of action and tree size in the orchard. Increased sprayer ground speed can reduce volume of pesticide applied and increase efficiency by reducing time and cost to spray orchards. The ground speed of airblast constant rate sprayers is known to affect spray deposition, with increased sprayer ground speed reducing spray droplet deposition in tree canopies (Salyani and Whitney 1990), and although variable rate sprayers may offer promise in orchard crops (Liu et al. 2013), they are not yet widely used in commercial peach operations. Studies in apple orchards comparing ground speeds of $2.4,3.2,4.0$, and $4.8 \mathrm{kph}$ showed that spray deposition was greater at lower speeds, with variability greatest at the highest speed (Travis et al. 1987b). Salyani and Whitney (1990) found that ground speeds of 1.6 to $6.4 \mathrm{kph}$ did not have a significant effect on mean deposition in the tree canopy. However, they also commented that variability of spray droplet deposition increased as tractor speed increased, and the sample location in a tree canopy affected spray deposition and interacted with speed. As noted above, although spray droplet deposition has been widely studied, the impact of any differences due to tractor speed, spray volume, or dose have rarely been translated into the impact on practical disease control. Was the resulting incidence and severity of disease affected by changes in spray droplet deposition characteristics resulting from the change in speed, volume, or dose? This appears to be a critical question, and there is likely a point of inflection in characteristics of droplet deposition that will reduce fungicide efficacy. Only in a few studies has spray volume or tractor speed and concentration of active ingredient and resulting impact on disease been studied in orchard or similar crops. Wicks and Nitschke (1986) found that neither volume (100 to 800 liters/ha) nor dose affected control of apple scab, although control of powdery mildew was affected. In contrast, Cross and Berrie (1990) applied a range of different sprayer volumes and rates to apple trees, and found that a conventional medium volume (500 liters/ha) applying the full manufacturer's dose was the most reliably effective method for reducing apple scab, and also for applying a full range of fungicides, insecticides, and nutrients. In juice grapes, although spray volume played a role in disease control (higher volume from airblast sprayers generally being more efficacious), fungicide type was more critical (Wise et al. 2010). Whether tractor speed in peach orchards can be increased (to reduce volume applied but maintain dose of active ingredient per unit area) to a point where peach scab control is not compromised but efficiency maximized has not been explored.

The goal of this study was to address the ramifications of tractor speed to apply fungicide to manage scab on peach. The objectives of the study were to ascertain whether there was any effect of increasing tractor speed as a tool to adjust volume applied while maintaining constant a.i. applied per hectare on i) spray deposition in the canopy of peach trees at different stages of canopy development, and ii) the subsequent impacts on the incidence and severity of peach scab.

\section{Materials and Methods}

Location. The experiment was conducted in 2015 and 2016 in a peach orchard (cv. O'Henry, 6 years old in 2015) in Peach Co., at the USDA-ARS-Southeastern Fruit and Tree Nut Research Laboratory, Byron, GA $\left(32^{\circ} 39^{\prime} 54^{\prime \prime} \mathrm{N}, 8^{\circ} 44^{\prime} 31^{\prime \prime} \mathrm{W}\right.$; elevation $\sim 156 \mathrm{~m}$ [509 ft]). The location has an annual precipitation of $\sim 1.81 \mathrm{~m}$. The soil type is a Faceville sandy loam (FoA; fine, Kaolintic, thermic Typic Kandiudult soil). Peach tree spacing in the orchard was $6 \mathrm{~m} \times 6 \mathrm{~m}$.

Spray application rates, tractor speeds, and orchard management. The peach trees were sprayed with fungicide to control peach scab at petal fall to $1 \%$ shuck split and at shuck split to $10 \%$ shuck off. The fungicide applied was the protectant Bravo Weatherstik (Syngenta Crop Protection LLC, Greensboro, NC) at 4.8 liters/ha (4.125 pints/acre). In 2015, the first and second sprays were applied on 5 and 13 April, and in 2016 on 24 March and 7 April. Imidan 70 W (Gowan Co., Yuma, AZ) at $2.24 \mathrm{~kg} / \mathrm{ha}$ ( $2 \mathrm{lb} / \mathrm{acre}$ ) was also applied at 14- to 21-day intervals, along with summer cover sprays (7- to 10-day intervals until trial completion) of sulfur (Yellow Jacket Sulfur, Georgia Gulf Sulfur Corporation, Valdosta, GA) at $10.09 \mathrm{~kg} / \mathrm{ha}$ (9 lb/acre).

A Durand Wayland 3-point hitch sprayer was used with seven hollow cone ceramic nozzles on each side, comprising $2 \times \# 5$ tips (upper 2 nozzles) and $5 \times \# 6$ tips (lower 5 nozzles). All swirl plates were \#45. The active ingredient was added to simulate equivalent a.i. per acre, but at different speeds (thus speeds of 3.2, 4.8, and 6.4 kph [2,3, and $4 \mathrm{mph}$ ] are equivalent to $1,403,935$, and 701 liters/ha [150,100, and 75 gallons per acre (gpa)], respectively) using the same nozzle set up but adding different quantities of a.i. to maintain rate per hectare (3.21, 4.82, and 6.43 liters [2.75, 4.125, and 5.50 pints]) of Bravo Weatherstik per 935 liters (100 gallons) at 3.2, 4.8, and $6.4 \mathrm{kph}$, respectively. Thus, tractor speed was used to manipulate volume applied while the concentration of a.i. was changed to maintain the same dose of a.i. per ha. There was a nontreated control for comparison. The experiment had a randomized complete block design with six blocks, with one replicate of each of the four treatments ( 3 speeds and a control) per block.

Spray card set up. Standard methods are used to characterize spray deposition. These include spray cards (Banaj et al. 2010; Fox et al. 2003; Salyani and Fox 1999; Syngenta 2002) that may be water sensitive or rely on dye, water-sensitive string (Salyani et al. 2006; Sumner 2004), patternators (Gil et al. 2013; Pergher 2004), and the use of chemical tracers (Herrington et al. 1981; Reilly et al. 2007).

Spray deposition can be measured as coverage and/or droplet number. We assessed both by using kromekote cards $(5.08 \mathrm{~cm} \times 7.62 \mathrm{~cm})$ 
and applying spray colored with Vision Pink dye (GarrCo Products Inc., Converse, IN) mixed at a rate of 0.95 liters (32 fl. oz.) in 935 liters of water. Cards (four per height on each of four marked bamboo poles) were placed attached to galvanized metal platforms at heights of $0.6,1.5$, and $2.4 \mathrm{~m}(2,5$, and $8 \mathrm{ft})$ on the bamboo poles (Fig. 1). Three consecutive trees (replicates) in a row that had typical canopy structure (and were not treatment trees for the disease control experiment) were selected. Four poles were placed transversely across the row in the canopy of each sample peach tree, such that there were two poles on each side of the tree trunk, one situated at $5.08 \mathrm{~cm}$, the other at $91 \mathrm{~cm}$ (36 in) from the trunk, respectively. Platforms and cards (coated surface to collect spray) were positioned on each pole such that there was a front and rear facing card in relation to the spray direction, and an upper and lower card (horizontal upper $=\mathrm{HU}$, horizontal lower $=\mathrm{HL}$, vertical front $=\mathrm{VF}$, and vertical back $=\mathrm{VB}$ ). Cards were changed after each spray test. Each test was repeated once on the day the experiment was run. Spray tests were performed with the tractor sprayer set up as described above (different speeds with the same nozzle set up). The experiment was done once in 2015 (16 June 2015) and three times in 2016 on 7 April, 15 June, and 25 July. A further spray deposition test was conducted in 2015 (17 June) to examine different combinations of hollow cone nozzles to maintain a constant volume (748 liters/ha [80 gpa]) at three speeds $(3.2,4.8$, and $6.4 \mathrm{kph})$. Hollow cone nozzles used in the study are presented (Table 1). All nozzle combinations were chosen per tabulated nozzle outputs (Teejet, Inc. Catalog 51A) and verified with a sprayer calibration. For all nozzle setups, the smaller volume nozzles were placed at the bottom of the sprayer, with the larger volume nozzles placed above.

Deposition on spray cards (\% area covered in pink dye) was analyzed using DropletScan software (WRK of Arkansas, LLC, Lonoke, AR).

Sampling and assessment of fruit. Peach trees were divided into four quadrants (north, east, south, and west faces), and each quadrant was divided into three heights. A sample of 20 peach fruit (or as many were available at that height and quadrant) were collected from each height $\times$ quadrant segment of the tree canopy. Thus, there were a total of 12 samples of fruit collected from each tree. The height strata center-points were situated between the card heights of $0.6,1.5$, and $2.4 \mathrm{~m}$, and so the height strata limits (where low gives way to middle and middle gives way to upper strata) were at 1.06 and $1.98 \mathrm{~m}$ (3.5 and $6.5 \mathrm{ft}$ ), respectively. The strata limits dictate sample height cutoff. To facilitate sample collection, marked bamboo poles with

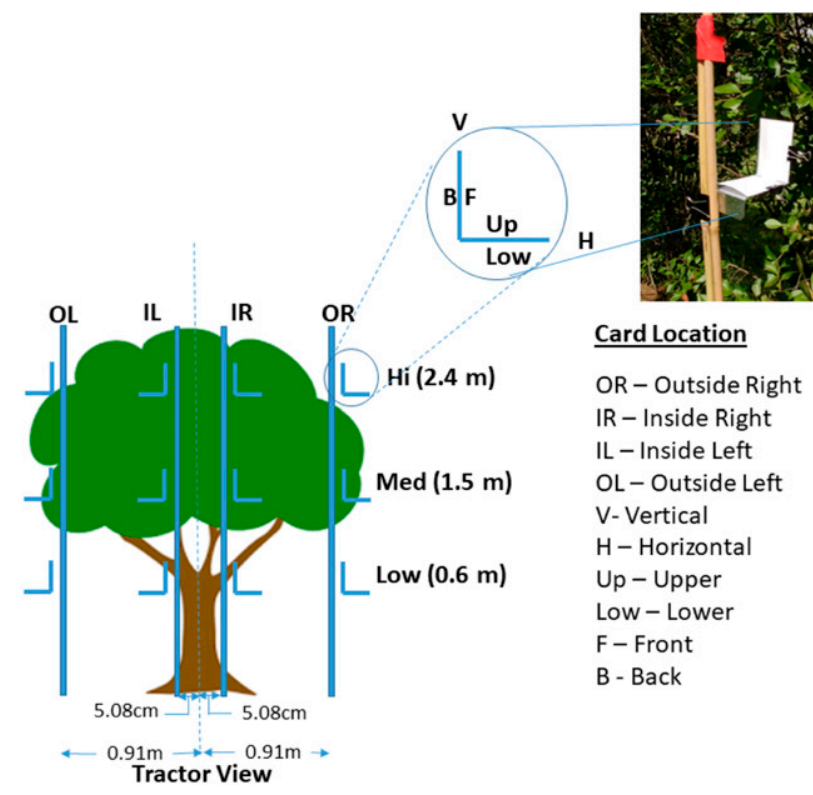

Fig. 1. Pole location, platform, and card placement for a single peach tree to collect droplet coverage on kromekote cards. colored tape (one color for cutoffs was used during sampling). Within the framework of the RCB design, there were main effects of treatment, block, tree quadrant, tree sample height, and interactions.

Peach fruit were sampled on 8 July in 2015 and 19 July in 2016. Fruit were transported to the lab and placed in a cooler at $6^{\circ} \mathrm{C}$ until assessment, which was completed within 2 days of sample collection. The number of peach scab lesions on each fruit was counted.

Daily rainfall data for the period 1 March to 30 June was collected for both 2015 and 2016 for the Byron location. Data were obtained from the University of Georgia Weather Network (http://www. georgiaweather.net/). As noted in the introduction, rainfall is important for driving epidemics of scab (Keitt 1917; Lan and Scherm 2003; Lawrence and Zehr 1982; Scherm et al. 2008).

Data analysis. All analyses were performed using SAS V9.4 (SAS, Cary, NC). Data were checked for normality and to confirm that they exhibited homoscedasticity of variance. Due to nonnormal distributions, the dependent variables (spray deposition and disease) were natural $\log \left(\log _{\text {exp }}\right)$ transformed prior to analysis, except for incidence of scabbed fruit (\%), which approximated to a normal distribution, and so was analyzed without transformation. Due to frequent small sample size of peach fruit samples from each of the four quadrants of the peach trees, the samples were pooled at each height. Control trees were not included in the analysis as the interest was primarily in comparing speeds/volume (treatments). However, data for the control peach trees is presented.

All spray deposition data were subject to analysis of variance using a generalized linear mixed model (GLIMMIX). Initially, each of the five experiment dates was analyzed independently. Fixed effects included speed, pole location, card height and card orientation on the platform, and the interactions. Run was a random effect in the model. Subsequently, the three dates the experiment was conducted in 2016 were subject to a further analysis of variance using a GLIMMIX, incorporating date as a fixed effect, with other fixed and random effects as already described. Disease data were subject to analysis of variance using a general linear model (GLM), with main effects of speed, height, and block. Dependent variables were incidence of scabbed fruit $(\%)$, number of lesions per fruit, and number of lesions per infected fruit. Means separation was by Tukey's HSD $(\alpha=0.05)$. Means were back transformed from the natural $\log$ as $\exp (n)$, where $\exp =2.7183$, and $\mathrm{n}$ is the mean value from the transformed data.

Linear regression analysis was used to explore the relationship between tractor speed and spray deposition at different heights on each of the different dates, and between the disease variables and tractor speed at different canopy sample heights. The disease incidence and severity data were normalized prior to linear regression analysis by taking percent reduction in disease compared with the control for each year. Thus, the normalized data from the two years were combined and linear regression analysis performed. The GLM analysis for the regression was checked for significance $(P \leq 0.05)$, and the coefficient of determination $\left(\mathrm{R}^{2}\right)$ used to assess the variation in $y$ (dependent or criterion variable) explained by $x$ (predictor or independent variable).

\section{Results}

Spray distribution: changing nozzles to apply spray at $\mathbf{7 4 8}$ liters/ha (16 Jun 2015). The analysis showed significant effects of several factors and their interaction (Supplementary Table S1). Regardless of nozzles, greatest spray deposition was at $3.2 \mathrm{kph}$ (12.0\%) compared with 4.8 and $6.4 \mathrm{kph}$ (9.7 and $8.0 \%$, respectively)

Table 1. Disc and swirl plate combinations to maintain 748 liters/ha at 3.2, 4.8 , and $6.4 \mathrm{kph}$ during the spray operations in a peach orchard (cv. O'Henry) on 16 June 2015, Byron, GA

\begin{tabular}{lcc}
\hline Speed (kph) & Disk + swirl plate & Disk + swirl plate \\
\hline 3.2 & $3 \times \# 5+\# 25$ & $4 \times \# 5+\# 23$ \\
4.8 & $5 \times \# 5+\# 25$ & $2 \times \# 6+\# 25$ \\
6.4 & $2 \times \# 5+\# 23$ & $5 \times \# 6+\# 45$ \\
\hline
\end{tabular}


(Table 2). The same trend was seen at each pole location. Overall, there was either significantly or numerically more spray deposited at the two outer pole locations. There was significantly less spray deposition at $0.6 \mathrm{~m}$ compared with $2.4 \mathrm{~m}$ card height at all speeds, and overall less deposition at $6.4 \mathrm{kph}$ compared with 3.2 and $4.8 \mathrm{kph}$, particularly low in the canopy at high speeds. Most spray was deposited on the VF cards $(19.6 \%)$ and least was deposited on the HL cards (4.9\%). Deposition on the HU and VB cards was similar (9.9 and $9.6 \%$, respectively).

Spray distribution: spray applied at $1,403,935$, and 701 liters/ ha (17 Jun 2015; 7 Apr, 16 Jun, and 16 Jul 2016). The results of the analysis showed that various main effects and their interactions were significant on different sample dates (Supplementary Table S1). The main effects of speed on the different dates showed that there was a consistent decline in spray deposition with increasing speed (Table 3). For example, on 7 Apr 2016 at 3.2, 4.8, and 6.4 kph, deposition was $28.1,20.7$, and $12.0 \%$, respectively. There was most often more deposition on cards placed higher in the canopy, except on 16 Jul 2016. For example, on 16 Jun 2016 at $0.6,1.5$, and $2.4 \mathrm{~m}$, deposition was $12.0,13.6$, and $15.5 \%$, respectively. The interactions for each height and tractor speed for each date tended to reflect the main effect relationships, although it was not entirely consistent (the interaction was significant on 17 Jun 2015 and 7 Apr 2016).

Although there were differences in deposition among pole locations on 17 Jun 2015 and 16 Jul 2016, numerically the differences were small (Table 4). For example, on 16 Jul 2016 at pole locations OL, IL, IR, and OR, deposition was 4.5, 4.5, 6.0, and 6.6\%. Although there were no significant interactions, there were differences among locations and heights at each date (driven by the main effects). Trends were consistent on all dates; only on 17 Jun 2015 and 7 Apr 2016 was there a consistent significant decline in spray coverage at all pole locations with increasing tractor speed. On the remaining dates there was a consistent numeric and sometimes significant decline in spray deposition with speed.

On all dates except 7 Apr 2016, greatest deposition either statistically or numerically was on the card oriented in the VF direction compared with the card orientation with the next greatest deposition (Table 5). For example, on 16 Jun 2016, the deposition on the VF card was $22.5 \%$ compared with $18.1 \%$ on the HU card, 13.9 on the VB card, and only $6.1 \%$ on the HL card.
The effect of spray date in 2016. Spray date had a significant effect on deposition (Supplementary Table S2). Two-way interactions between spray date $\times$ speed and spray date $\times$ pole location, spray date $\times$ card height, spray date $\times$ card orientation, pole location $\times$ card height, pole location $\times$ card orientation, and card height $\times$ card orientation were also significant. Some three-way interactions were also significant. There was a decline in deposition with later dates: on 7 Apr, 16 Jun, and $16 \mathrm{Jul}$, deposition was 19.0, 13.6, and 5.3\%, respectively (Table 6). Overall deposition declined with speed-the

Table 3. Main effects of tractor speed at 3.2, 4.8, and $6.4 \mathrm{kph}$ applying 701, 935, and 1,403 liters/ha, respectively, and height, and interactions of speed $\times$ height on the percentage card coverage with spray deposition in a peach orchard (cv. O'Henry) on four dates in 2015 and 2016, Byron, GA

\begin{tabular}{|c|c|c|c|c|c|c|}
\hline \multirow[b]{3}{*}{ Year } & \multirow[b]{3}{*}{ Month } & \multirow[b]{3}{*}{ Speed (kph) } & \multicolumn{4}{|c|}{ Spray card coverage (\%) } \\
\hline & & & \multicolumn{3}{|c|}{ Height (m) } & \multirow[b]{2}{*}{ Mean } \\
\hline & & & 2.4 & 1.5 & 0.6 & \\
\hline \multirow[t]{4}{*}{2015} & 17 Jun & 3.2 & $9.2 \mathrm{a}^{\mathrm{x}, \mathrm{y}, \mathrm{z}}$ & $6.3 \mathrm{bc}$ & $6.2 \mathrm{bc}$ & $7.1 \mathrm{~h}$ \\
\hline & & 4.8 & $10.1 \mathrm{a}$ & $7.6 \mathrm{ab}$ & $7.4 \mathrm{ab}$ & $8.3 \mathrm{~g}$ \\
\hline & & 6.4 & $5.2 \mathrm{c}$ & $3.9 \mathrm{~d}$ & $1.9 \mathrm{e}$ & $3.3 \mathrm{i}$ \\
\hline & & Mean & 7.81 & $5.6 \mathrm{k}$ & $4.4 \mathrm{j}$ & \\
\hline \multirow[t]{4}{*}{2016} & $7 \mathrm{Apr}$ & 3.2 & $37.6 \mathrm{a}$ & $33.0 \mathrm{ab}$ & $18.0 \mathrm{c}$ & $28.1 \mathrm{~g}$ \\
\hline & & 4.8 & $26.7 \mathrm{~b}$ & $27.0 \mathrm{~b}$ & $12.2 \mathrm{~d}$ & $20.7 \mathrm{~h}$ \\
\hline & & 6.4 & $13.4 \mathrm{~d}$ & $14.4 \mathrm{~cd}$ & $8.9 \mathrm{e}$ & $12.0 \mathrm{i}$ \\
\hline & & Mean & 23.81 & 23.41 & $12.5 \mathrm{k}$ & \\
\hline \multirow[t]{4}{*}{2016} & 16 Jun & 3.2 & $17.4 \mathrm{a}$ & $15.9 \mathrm{a}$ & $13.0 \mathrm{abc}$ & $15.3 \mathrm{~g}$ \\
\hline & & 4.8 & $15.9 \mathrm{a}$ & $14.4 \mathrm{ab}$ & $13.9 \mathrm{ab}$ & $14.7 \mathrm{~g}$ \\
\hline & & 6.4 & $13.6 \mathrm{ab}$ & $11.1 \mathrm{bc}$ & $9.5 \mathrm{c}$ & $11.3 \mathrm{~h}$ \\
\hline & & Mean & 15.51 & $13.6 \mathrm{kl}$ & $12.0 \mathrm{k}$ & \\
\hline \multirow[t]{4}{*}{2016} & $16 \mathrm{Jul}$ & 3.2 & $7.8 \mathrm{ab}$ & $7.9 \mathrm{ab}$ & $10.1 \mathrm{a}$ & $8.5 \mathrm{~g}$ \\
\hline & & 4.8 & $5.2 \mathrm{bc}$ & $5.2 \mathrm{bc}$ & $4.5 \mathrm{~cd}$ & $5.0 \mathrm{~h}$ \\
\hline & & 6.4 & $3.3 \mathrm{~cd}$ & $2.9 \mathrm{~d}$ & $4.8 \mathrm{bcd}$ & $3.6 \mathrm{i}$ \\
\hline & & Mean & 5.11 & 4.91 & 6.01 & \\
\hline
\end{tabular}

x Tukey's separations of least square means (natural log back transformed values) are presented $(\alpha=0.05)$.

y Different letters in each main effect or interaction group indicate significant differences among those means.

${ }^{\mathrm{z}} \mathrm{F}$ and $P$ values for the main effects and interactions are presented in Supplementary Table S1.

Table 2. Main effects of tractor speed, pole position, height, and card orientation and interactions of speed $\times$ location and speed $\times$ height on the percentage card coverage with spray deposition using different nozzles to apply constant 748 liters/ha at 3.2, 4.8, and $6.4 \mathrm{kph}$ in a peach orchard (cv. O'Henry) on 16 June 2015 , Byron, GA

\begin{tabular}{|c|c|c|c|c|c|c|}
\hline \multirow[b]{2}{*}{ Speed $\times$ location } & \multirow[b]{2}{*}{ Speed (kph) } & \multicolumn{4}{|c|}{ Location (transverse across tree) ${ }^{v}$} & \multirow[b]{2}{*}{ Mean } \\
\hline & & OL & IL & IR & OR & \\
\hline & 3.2 & $12.1 \mathrm{ab}^{\mathrm{w}, \mathrm{x}, \mathrm{y}}$ & $10.9 \mathrm{abc}$ & $11.1 \mathrm{abc}$ & $14.1 \mathrm{a}$ & $12.0 \mathrm{~g}$ \\
\hline & 4.8 & $10.3 \mathrm{abcd}$ & 9.0 bcde & 7.9 cde & $11.8 \mathrm{ab}$ & $9.7 \mathrm{~h}$ \\
\hline & 6.4 & 8.9 bcde & $7.3 \mathrm{de}$ & $6.4 \mathrm{e}$ & $10.0 \mathrm{abcd}$ & $8.0 \mathrm{i}$ \\
\hline & Mean & $10.4 \mathrm{kl}$ & $8.9 \mathrm{jk}$ & $8.2 \mathrm{j}$ & 11.91 & \\
\hline & & & Ieight (m) & & & \\
\hline \multirow[t]{5}{*}{ Speed $\times$ height } & Speed (kph) & 2.4 & 1.5 & 0.6 & Mean & \\
\hline & 3.2 & $15.4 \mathrm{a}^{\mathrm{w}, \mathrm{x}, \mathrm{y}}$ & $11.4 \mathrm{abc}$ & $9.8 \mathrm{bcd}$ & $12.0 \mathrm{~g}$ & \\
\hline & 4.8 & $13.2 \mathrm{ab}$ & $7.2 \mathrm{de}$ & $9.5 \mathrm{~cd}$ & $9.7 \mathrm{~h}$ & \\
\hline & 6.4 & $12.8 \mathrm{abc}$ & $6.4 \mathrm{e}$ & $6.3 \mathrm{e}$ & $8.0 \mathrm{i}$ & \\
\hline & Mean & 13.81 & $8.0 \mathrm{k}$ & $8.4 \mathrm{k}$ & & \\
\hline \multirow[t]{5}{*}{ Card position } & Position (on platform) ${ }^{\mathrm{z}}$ & & & & & \\
\hline & $\mathrm{HL}$ & $4.9 \mathrm{c}$ & & & & \\
\hline & $\mathrm{HU}$ & $9.9 \mathrm{~b}$ & & & & \\
\hline & VB & $9.6 \mathrm{~b}$ & & & & \\
\hline & $\mathrm{VF}$ & $19.6 \mathrm{a}$ & & & & \\
\hline
\end{tabular}

\footnotetext{
v Pole location: $\mathrm{OL}=$ outer left, $\mathrm{IL}=$ inner left, $\mathrm{IR}=$ inner right, $\mathrm{OR}=$ outer right.

w Tukey's separations of least square means (natural log back transformed values) are presented $(\alpha=0.05)$.

$x$ Different letters in each main effect or interaction group indicate significant differences among those means.

y $\mathrm{F}$ and $P$ values for the main effects and interactions are presented in Supplementary Table S1.

$\mathrm{z}$ Card position on platform: $\mathrm{HL}=$ horizontal lower, $\mathrm{HU}=$ horizontal upper, $\mathrm{VB}=$ vertical back, $\mathrm{VF}=\mathrm{vertical}$ front.
} 
characteristics of speed on individual dates are as described above. Deposition on $7 \mathrm{Apr}$ and 16 Jun was least at $0.6 \mathrm{~m}$ compared with $2.4 \mathrm{~m}$ (12.5 and $23.8 \%$, and 12.0 and $15.5 \%$, respectively), but there was no effect of height on $16 \mathrm{Jul}$. Overall there was a trend for slightly greater deposition on the right side of the peach trees compared with the left side (the difference was significant, but was small numerically, ranging from 10.1 to $12.0 \%$ ). However, there was no difference among pole locations on 7 Apr or 16 Jun, but on 16 Jul there was a small but significantly greater deposition at the outer and inner right pole location (6.6 and $6.0 \%$, respectively), compared with the inner and outer left pole location (both $4.5 \%$ deposition, respectively).

Relationships between speed and deposition. On all dates in both 2015 and 2016, there was a discernible negative linear relationship $\left(\mathrm{R}^{2}=0.36-0.94\right)$ between speed and spray deposition-the greater the tractor speed, the less deposition on the spray cards (Fig. 2). However, the relationship was very weak and was not significant on 17 Jun $2015\left(\mathrm{~F}=4.7, P=0.07, \mathrm{R}^{2}=0.40\right)$, or $16 \mathrm{Jun}$ $\left(\mathrm{F}=3.9, P=0.09, \mathrm{R}^{2}=0.36\right)$ and $16 \mathrm{Jul}\left(\mathrm{F}=4.5, P=0.07, \mathrm{R}^{2}=\right.$ $0.39) 2016$.

Incidence and severity of peach scab. Scab epidemics developed in both treated and nontreated peach trees in both 2015 and 2016. The incidence of scabbed fruit on nontreated trees was $88.7 \%$ and $88.2 \%$ in 2015 and 2016, respectively (Table 7). Both number of lesions per fruit and number of lesions per infected fruit on the control trees were severe in 2015 (34.6 and 40.0 lesions, respectively) and 2016 (95.0 and 108.8 lesions, respectively). Although rainfall totals during the growing season in $2015(36.27 \mathrm{~cm})$ and $2016(38.51 \mathrm{~cm})$ were similar (Supplementary Fig. S1), the distribution and pattern were different. In 2016, there was a single rain event of $13.06 \mathrm{~cm}$ on 1 April, and only $7.34 \mathrm{~cm}$ fell during the remainder of the month; in 2015, rainfall was relatively evenly distributed. This is a critical period of peach fruit development and coincides with peaks in inoculum of $V$. carpophila (Scherm et al. 2008), and hence when fungicide is applied to control peach scab.

Table 4. Main effects of tractor speed at 3.2, 4.8, and 6.4 kph applying 701, 935 , and 1,403 liters/ha, respectively, and canopy position, and interactions of speed $\times$ canopy position on the percentage card coverage with spray deposition in a peach orchard (cv. O'Henry) on four dates in 2015 and 2016, Byron, GA

\begin{tabular}{|c|c|c|c|c|c|c|c|}
\hline \multirow[b]{3}{*}{ Year } & \multirow[b]{3}{*}{ Month } & \multirow{3}{*}{$\begin{array}{c}\text { Speed } \\
(\mathbf{k p h})\end{array}$} & \multicolumn{5}{|c|}{ Spray card coverage $(\%)$} \\
\hline & & & \multicolumn{4}{|c|}{ Location (across tree) $^{\mathrm{w}}$} & \multirow[b]{2}{*}{ Mean } \\
\hline & & & OL & IL & IR & OR & \\
\hline \multirow[t]{4}{*}{2015} & 17 Jun & 3.2 & $6.0 \mathrm{~b}^{\mathrm{x}, \mathrm{y}, \mathrm{z}}$ & $6.2 \mathrm{ab}$ & $8.7 \mathrm{ab}$ & $7.8 \mathrm{ab}$ & $7.1 \mathrm{~h}$ \\
\hline & & 4.8 & $7.6 \mathrm{ab}$ & $7.6 \mathrm{ab}$ & $8.8 \mathrm{ab}$ & $9.2 \mathrm{a}$ & $8.3 \mathrm{~g}$ \\
\hline & & 6.4 & $3.1 \mathrm{c}$ & $2.8 \mathrm{c}$ & $3.3 \mathrm{c}$ & $3.9 \mathrm{c}$ & $3.3 \mathrm{i}$ \\
\hline & & Mean & 6.31 & $5.1 \mathrm{k}$ & $5.2 \mathrm{k}$ & 6.61 & \\
\hline \multirow[t]{4}{*}{2016} & 7 Apr & 3.2 & $28.5 \mathrm{a}$ & $26.3 \mathrm{ab}$ & $28.5 \mathrm{a}$ & $29.3 \mathrm{a}$ & $28.1 \mathrm{~g}$ \\
\hline & & 4.8 & $21.3 \mathrm{ab}$ & $20.1 \mathrm{~b}$ & $21.7 \mathrm{ab}$ & $19.7 \mathrm{~b}$ & $20.7 \mathrm{~h}$ \\
\hline & & 6.4 & $12.8 \mathrm{c}$ & $11.3 \mathrm{c}$ & $12.0 \mathrm{c}$ & $12.1 \mathrm{c}$ & $12.0 \mathrm{i}$ \\
\hline & & Mean & 19.81 & 18.11 & 19.51 & 19.11 & \\
\hline \multirow[t]{4}{*}{2016} & 16 Jun & 3.2 & $16.9 \mathrm{a}$ & $14.5 \mathrm{abc}$ & $14.9 \mathrm{abc}$ & $15.1 \mathrm{abc}$ & $15.3 \mathrm{~g}$ \\
\hline & & 4.8 & $15.4 \mathrm{abc}$ & $13.5 \mathrm{abc}$ & $14.3 \mathrm{abc}$ & $15.7 \mathrm{ab}$ & $14.7 \mathrm{~g}$ \\
\hline & & 6.4 & $11.9 \mathrm{abc}$ & $10.4 \mathrm{c}$ & $12.2 \mathrm{abc}$ & $10.8 \mathrm{bc}$ & $11.3 \mathrm{~h}$ \\
\hline & & Mean & 14.61 & 12.61 & 13.71 & 13.71 & \\
\hline \multirow[t]{4}{*}{2016} & $16 \mathrm{Jul}$ & 3.2 & $6.9 \mathrm{abc}$ & $6.6 \mathrm{bcd}$ & $12.3 \mathrm{a}$ & $9.5 \mathrm{ab}$ & $8.5 \mathrm{~g}$ \\
\hline & & 4.8 & $4.6 \mathrm{cdef}$ & $5.0 \mathrm{cde}$ & $4.9 \mathrm{cdef}$ & $5.4 \mathrm{bcd}$ & $5.0 \mathrm{~h}$ \\
\hline & & 6.4 & 2.9 ef & $2.7 \mathrm{f}$ & $3.6 \mathrm{def}$ & 5.7 bcde & $3.6 \mathrm{i}$ \\
\hline & & Mean & $4.5 \mathrm{k}$ & $4.5 \mathrm{k}$ & 6.01 & 6.61 & \\
\hline
\end{tabular}

${ }^{\text {w }}$ Pole location: $\mathrm{OL}=$ outer left, $\mathrm{IL}=$ inner left, $\mathrm{IR}=$ inner right, $\mathrm{OR}=$ outer right.

x Tukey's separations of least square means (natural log back transformed values) are presented $(\alpha=0.05)$.

y Different letters in each main effect or interaction group indicate significant differences among those means.

${ }^{\mathrm{z}} \mathrm{F}$ and $P$ values for the main effects and interactions are presented in Supplementary Table S1.
The results of the analysis for 2015 and 2016 for incidence of infected fruit, lesions per fruit, and lesions per infected fruit are presented (Supplementary Table S3). There was a lower mean incidence of peach fruit with scab at speeds of $6.4 \mathrm{kph}$ compared with speeds of $3.2 \mathrm{kph}$ in 2015 (38.3 and 60.0\%, respectively) and 2016 (40.4 and 64.2\%, respectively) (Table 7). A tractor speed of 4.8 $\mathrm{kph}$ resulted in an intermediate incidence and was either significantly (2015) or numerically (2016) higher compared with the incidence at $6.4 \mathrm{kph}$. There was difference in mean incidence at different heights in either year. Among the interactions (significant only in 2016), only at $0.6 \mathrm{~m}$ was the mean incidence of scabbed fruit significantly less at $6.4 \mathrm{kph}$ compared with the other speeds (at 1.5 and $2.4 \mathrm{~m}$, incidence was not significantly different among heights, although incidence was always numerically less at $6.4 \mathrm{kph}$ compared with $3.2 \mathrm{kph}$ ).

The number of lesions per fruit was least on those peach trees sprayed at $6.4 \mathrm{kph}$ compared with other speeds in 2015 (8.1, 10.8, and 3.6 lesions per fruit at $3.2,4.8$, and $6.4 \mathrm{kph}$, respectively), but there was no difference in the number of lesions per fruit at any speed in $2016(11.2,8.6$, and 9.9 lesions per fruit at 3.2, 4.8, and $6.4 \mathrm{kph}$, respectively) (Table 7). There was no effect of sample height on the number of lesions per fruit in either year. Although interactions were not significant in either year, in 2015 the fewest lesions at any height either significantly or numerically were invariably observed at 6.4 $\mathrm{kph}$. In 2016, there was no difference in lesion counts per fruit among heights and speeds.

Similarly the number of lesions per infected fruit was least on those trees sprayed at $6.4 \mathrm{kph}$ compared with other speeds in 2015 $(14.8,20.7$, and 10.6 lesions per fruit at $3.2,4.8$, and $6.4 \mathrm{kph}$, respectively), but there was no difference in the number of lesions per infected fruit at any speed in $2016(20.2,17.5$, and 20.5 lesions per fruit at 3.2, 4.8, and $6.4 \mathrm{kph}$, respectively) (Table 7). There was no effect of sample height on the number of lesions per fruit in either year. Among the interactions in 2015, significantly fewest lesions per infected fruit were observed at $6.4 \mathrm{kph}$ compared with $4.8 \mathrm{kph}$ at $0.6 \mathrm{~m}$, and at $6.4 \mathrm{kph}$ compared with $4.8 \mathrm{kph}$ at $1.5 \mathrm{~m}$, and at $6.4 \mathrm{kph}$ compared with $4.8 \mathrm{kph}$ at $2.4 \mathrm{~m}$. In all other cases, the number of lesions was numerically lower at $6.4 \mathrm{kph}$ compared with 3.2 or $4.8 \mathrm{kph}$ at all heights. In 2016, there was no difference in lesion counts per infected fruit among heights and speeds. Numeric differences were not consistent in 2016.

Relationships between tractor speed, height, and disease reduction. There was a linear relationship between percentage change in incidence of scabbed fruit and tractor speed (Fig. 3). This relationship was significant for all heights $\left(\mathrm{R}^{2}=0.68-0.76\right)$. There was no discernible relationship between the percentage change in numbers of scab lesions per fruit or per infected fruit and tractor speed (numbers were variable, particularly at $4.8 \mathrm{kph}$ ).

\section{Discussion}

Tractor speed affected spray droplet deposition in the peach trees. In the spray deposition experiment where nozzles were changed to

Table 5. Main effect of spray card orientation on the percentage card coverage with spray deposition in a peach orchard (cv. O'Henry) on four dates in 2015 and 2016, Byron, GA

\begin{tabular}{lccccc}
\hline & \multicolumn{2}{c}{$\mathbf{2 0 1 5}$} & & \multicolumn{3}{c}{$\mathbf{2 0 1 6}$} \\
\cline { 2 - 2 } \cline { 5 - 6 } Position (on platform) $^{\mathbf{w}}$ & $\mathbf{1 6 ~ J u n}$ & & $\mathbf{7 ~ A p r}$ & $\mathbf{1 6 ~ J u n}$ & 16 Jul \\
\hline HL & $3.5 \mathrm{~d}^{\mathrm{x}, \mathrm{y}, \mathrm{z}}$ & & $10.0 \mathrm{c}$ & $6.1 \mathrm{~d}$ & $1.5 \mathrm{c}$ \\
HU & $6.7 \mathrm{~b}$ & & $21.7 \mathrm{~b}$ & $18.1 \mathrm{~b}$ & $8.3 \mathrm{ab}$ \\
VB & $4.3 \mathrm{c}$ & & $26.4 \mathrm{a}$ & $13.9 \mathrm{c}$ & $6.6 \mathrm{~b}$ \\
VF & $10.8 \mathrm{a}$ & & $23.4 \mathrm{ab}$ & $22.5 \mathrm{a}$ & $10.0 \mathrm{a}$ \\
\hline
\end{tabular}

${ }^{w}$ Card position on platform: $\mathrm{HL}=$ horizontal lower, $\mathrm{HU}=$ horizontal upper, $\mathrm{VB}=$ vertical back, $\mathrm{VF}=$ vertical front.

$\mathrm{x}$ Tukey's separations of least square means (natural log back transformed values) are presented $(\alpha=0.05)$.

y Different letters in each main effect or interaction group indicate significant differences among those means.

z $F$ and $P$ values for the main effects and interactions are presented in Supplementary Table $\mathrm{S} 1$. 
maintain the same volume applied per ha at different speeds, different spray droplet coverage characteristics resulted. Thus, a speed of $4.8 \mathrm{kph}$ resulted in greatest droplet deposition compared with 3.2 or $6.4 \mathrm{kph}$, although numerically droplet coverage was close to that at $3.2 \mathrm{kph}$. This leads us to believe that speed affects droplet deposition on trees when using an airblast sprayer in peach orchards, as has been

Table 6. Main effects of date, tractor speed, sample height, and pole position, and interactions of date $\times$ speed, date $\times$ sample height, and date $\times$ pole position on the percentage card coverage with spray deposition as applied using an airblast sprayer in a peach orchard (cv. O'Henry) on 3 dates in 2016, at Byron, GA

\begin{tabular}{|c|c|c|c|c|c|}
\hline \multirow[b]{2}{*}{ Interaction } & \multirow[b]{2}{*}{ Variable } & \multicolumn{3}{|c|}{ Date } & \multirow[b]{2}{*}{ Mean } \\
\hline & & 7 Apr & 16 Jun & $16 \mathrm{Jul}$ & \\
\hline \multirow[t]{5}{*}{ Date $\times$ speed } & Speed (kph) & & & & \\
\hline & 3.2 & $28.1 \mathrm{a}^{\mathrm{w}, \mathrm{x}, \mathrm{y}}$ & $15.3 \mathrm{c}$ & $8.5 \mathrm{f}$ & $15.4 \mathrm{i}$ \\
\hline & 4.8 & $20.7 \mathrm{~b}$ & $14.7 \mathrm{c}$ & $5.0 \mathrm{~g}$ & $11.5 \mathrm{j}$ \\
\hline & 6.4 & $12.0 \mathrm{de}$ & $11.3 \mathrm{e}$ & $3.6 \mathrm{~h}$ & $7.9 \mathrm{k}$ \\
\hline & Mean & $19.1 \mathrm{n}$ & $13.6 \mathrm{~m}$ & 5.31 & \\
\hline \multirow[t]{5}{*}{ Date $\times$ card height } & Height (m) & & & & \\
\hline & 0.6 & $12.5 \mathrm{c}$ & $12.0 \mathrm{c}$ & $6.0 \mathrm{~d}$ & $9.7 \mathrm{j}$ \\
\hline & 1.5 & $23.4 \mathrm{a}$ & $13.6 \mathrm{bc}$ & $4.9 \mathrm{~d}$ & $11.6 \mathrm{i}$ \\
\hline & 2.4 & $23.8 \mathrm{a}$ & $15.5 \mathrm{~b}$ & $5.1 \mathrm{~d}$ & $12.4 \mathrm{i}$ \\
\hline & Mean & $19.1 \mathrm{n}$ & $13.6 \mathrm{~m}$ & 5.31 & \\
\hline \multirow[t]{6}{*}{ Date $\times$ pole location } & $\begin{array}{l}\text { Pole location } \\
\text { (on platform) }^{\mathrm{z}}\end{array}$ & & & & \\
\hline & OR & $19.1 \mathrm{ab}$ & $13.7 \mathrm{c}$ & $6.6 \mathrm{~d}$ & $12.0 \mathrm{i}$ \\
\hline & IR & $19.5 \mathrm{a}$ & $13.7 \mathrm{c}$ & $6.0 \mathrm{~d}$ & $11.7 \mathrm{i}$ \\
\hline & IL & $18.1 \mathrm{ab}$ & $12.6 \mathrm{c}$ & $4.5 \mathrm{e}$ & $10.1 \mathrm{j}$ \\
\hline & OL & $19.8 \mathrm{a}$ & $14.6 \mathrm{bc}$ & $4.5 \mathrm{e}$ & $10.9 \mathrm{ij}$ \\
\hline & Mean & $19.1 \mathrm{n}$ & $13.6 \mathrm{~m}$ & 5.31 & \\
\hline
\end{tabular}

w Tukey's separations of least square means (natural log back transformed values) are presented $(\alpha=0.05)$.

${ }^{x}$ Different letters in each main effect or interaction group indicate significant differences among those means.

y $\mathrm{F}$ and $P$ values for the main effects and interactions are presented in Supplementary Table $\mathrm{S} 2$.

z Pole location: $\mathrm{OL}=$ outer left, $\mathrm{IL}=$ inner left, $\mathrm{IR}=$ inner right, $\mathrm{OR}=$ outer right. noted in other orchard crops (Salyani and Whitney 1990; Travis et al. 1987b). Droplet momentum has more forward direction when released from a nozzle at higher forward speed, which could contribute to the lower deposition we saw at $6.4 \mathrm{kph}$.

In the four experiments maintaining constant nozzle output at different speeds (resulting in 1,403, 935, and 701 liters/ha), higher speed most often reduced deposition. As noted above, this has been described previously for other tree crops (Salyani and Whitney 1990; Travis et al. 1987b). However, the reason for the inconsistency on 16 Jun 2016, when the $4.8 \mathrm{kph}$ (935 liters/ha) speed had least deposition is unknown, but in all other cases the applied liters/ha and speed was consistent in regard to observed spray deposition. Furthermore, in three of the four experiments, the linear relationships at all sample heights between speed and deposition confirmed the reduced deposition at higher speeds.

Date affected the spray deposition in 2016. Peach foliage and fruit develop during the season, forming a screen to spray penetration. Thus, it is not surprising that later application dates resulted in a lower deposition, as has been observed in apple trees (Herrington et al. 1981; Travis et al. 1987a). The deposition on peach trees was greatly reduced at all heights on consecutive dates, which may not be as big an issue for peach scab management as the most critical sprays for control are applied at petal fall to $1 \%$ shuck split and at shuck split to $10 \%$ shuck off (Blaauw et al. 2019). However, cover sprays are applied after this date, and clearly development of foliage in peach trees will affect deposition as the season progresses, which could have ramifications for management of other diseases and pests. Early in the season, spray deposition was most often greatest in the upper canopy at the slowest speed, and least in the lower canopy at the highest speed. This may well be a result of sprayer set up projecting spray to the upper and middle canopy rather than directing the spray more toward $0.6 \mathrm{~m}$ and below, where relatively little foliage or peach fruit are positioned. Although pole position affected spray coverage, the effect tended to be small, but the marked reduction in coverage with date for all pole locations was likely due to canopy development. There is less peach foliage early in the season, so more droplets pass through the canopy. Card orientation affected deposition: with the exception of the 7 Apr 2016 experiment when the VB card had numerically the greatest deposition (not significantly
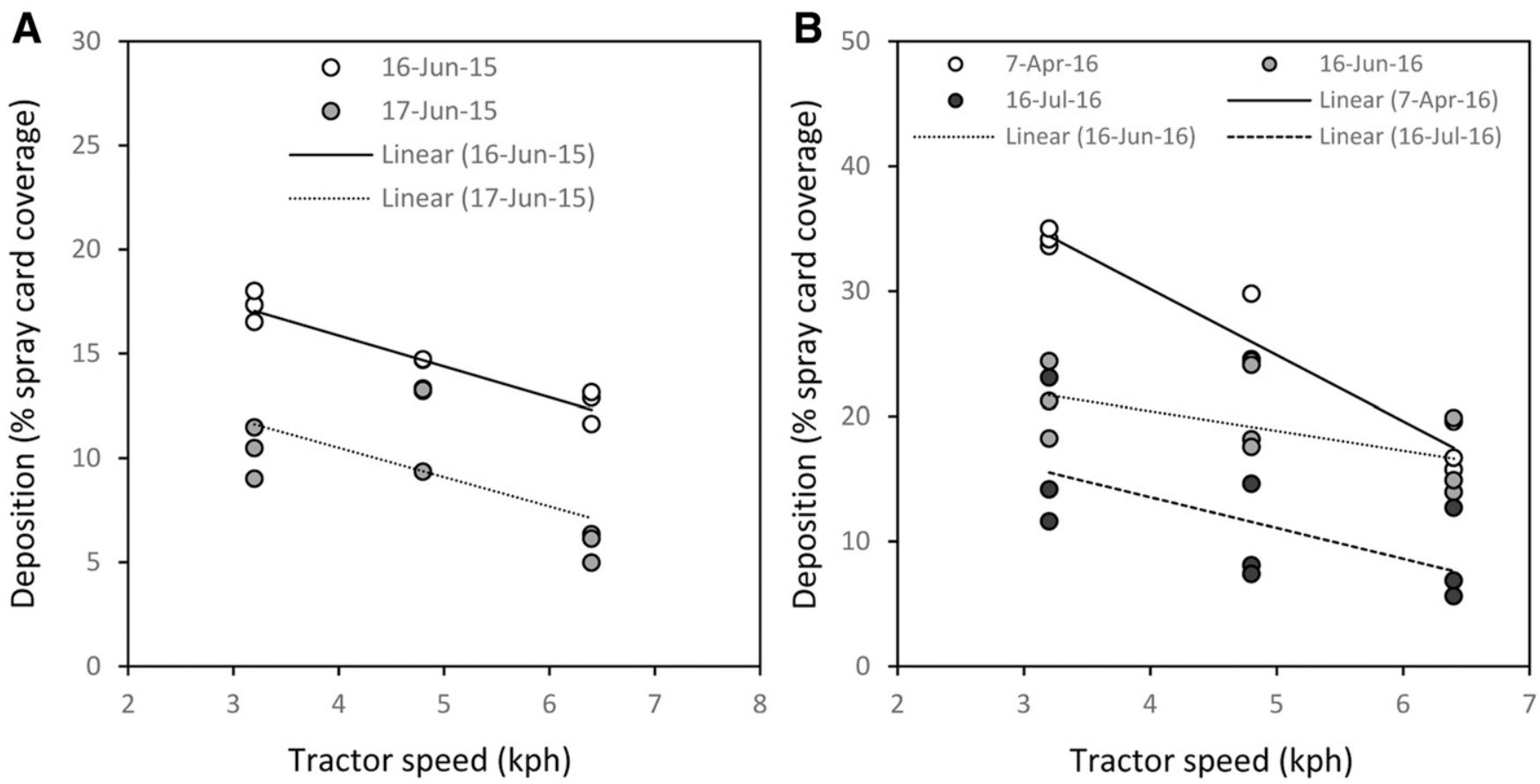

Fig. 2. The relationship between mean percentage card coverage on each replicate tree and tractor speeds for each test date in 2015 (A) and 2016 (B). Linear relationships are defined for the effect of tractor speed (different nozzles to maintain 748 liters/ha) on 16 Jun 2015 ( $F=47.6, P \leq 0.0002 ; y=21.8-1.48 x ; R^{2}=0.87$ ); the effect of tractor speed (same nozzles resulting in 701, 935, and 1,403 liters/ha) on $17 \mathrm{Jun} 2015\left(\mathrm{~F}=4.7, P=0.07 ; \mathrm{y}=16.1-1.41 \mathrm{x} ; \mathrm{R}^{2}=0.40\right)$, and in 2016 on $7 \mathrm{Apr}(\mathrm{F}=106.4, P<0.0001 ; \mathrm{y}=51.3-$ $\left.5.28 x ; R^{2}=0.94\right), 16$ Jun $\left(F=3.9, P=0.09 ; y=26.7-1.58 x ; R^{2}=0.36\right)$, and 16 Jul $\left(F=4.5, P=0.07 ; y=23.4-2.47 x ; R^{2}=0.39\right)$. 
so), the card located at the VF position invariably had the most spray deposited, which is consistent with the fact that this is the card most directly exposed to the inbound droplets from the airblast sprayer. The HU card also received as much spray as, or was second to, the VF card: it may be that the upper side of peach fruit is the most exposed to inoculum and subsequent development of peach scab (Bock et al. 2011), so the observations that the spray deposition on this orientation was high is useful to know. The horizontal lower card orientation invariably had least deposition as it had the most limited direct exposure to spray. Thus, several factors were noted to affect spray coverage in this study including date, speed, transverse location in the canopy, height, and orientation relative to inbound spray. Wherever fungicide deposition is insufficient, peach scab can potentially develop.

We found that the incidence of scabbed peach fruit was consistently reduced at higher tractor speeds $(6.4 \mathrm{kph})$ compared with slower tractor speeds. Higher tractor speeds apply a lower spray volume, but the pesticide is more concentrated, so if coverage is adequate, dose is higher. Although Wicks and Nitschke (1986) observed that neither volume (100 to 800 liters/ha) nor rate of a.i. affected control of apple scab, control of powdery mildew was affected. In a study with contrasting results, Cross and Berrie (1990) found that a medium volume (500 liters/ha) and full dose was the most reliable for reducing scab on apple. Although neither of these studies compared speed and volume the way we did, they indicate that both volume and dose are important components of the disease control equation. Tractor speed may provide an additional way to manipulate these variables due to the effect on spray deposition (Travis et al. 1987b). The results of our study were borne out by the linear relationship between the percent reduction in disease incidence, and speed at all heights. Lower volumes of more concentrated fungicide, combined with sufficient spray coverage, may explain the effect on peach scab incidence in the tree canopies in these studies.

However, effects of tractor speed on measures of peach scab severity (lesions per fruit and lesions per infected fruit) were either more subtle or nonexistent. The number of lesions per fruit or per infected fruit was generally statistically equivalent at $3.2,4.8$, and $6.4 \mathrm{kph}$ or in some

Table 7. The effect of tractor speed adjusted to apply 701 (6.4 kph), 935 (4.8 kph), and 1,403 liters/ha $(3.2 \mathrm{kph})$ at a constant rate of active ingredient per area and peach tree sample height $(0.6,1.5$, and $2.4 \mathrm{~m})$ on the incidence (\% infected fruit), the number of lesions per fruit, and number of lesions per infected fruit of peach scab caused by Venturia carpophila

\begin{tabular}{|c|c|c|c|c|c|c|c|c|c|}
\hline \multirow[b]{3}{*}{ Dependent variable } & \multirow[b]{3}{*}{ Speed (kph) } & \multicolumn{4}{|c|}{2015} & \multicolumn{4}{|c|}{2016} \\
\hline & & \multicolumn{3}{|c|}{ Height (m) } & \multirow[b]{2}{*}{ Mean } & \multicolumn{3}{|c|}{ Height (m) } & \multirow[b]{2}{*}{ Mean } \\
\hline & & 0.6 & 1.5 & 2.4 & & 0.6 & 1.5 & 2.4 & \\
\hline \multirow[t]{5}{*}{ Incidence of infected fruit (\%) } & Control & 90.9 & 91.3 & 83.9 & 88.7 & 89.7 & 89.8 & 85.0 & 88.2 \\
\hline & 3.2 & $57.5 \mathrm{ab}^{\mathrm{x}, \mathrm{y}, \mathrm{z}}$ & $57.5 \mathrm{ab}$ & $65.0 \mathrm{a}$ & $60.0 \mathrm{f}$ & $68.6 \mathrm{a}$ & $56.2 \mathrm{ab}$ & $67.8 \mathrm{a}$ & $64.2 \mathrm{f}$ \\
\hline & 4.8 & $59.8 \mathrm{a}$ & $57.1 \mathrm{ab}$ & $60.5 \mathrm{a}$ & $59.2 \mathrm{f}$ & $58.8 \mathrm{ab}$ & $47.4 \mathrm{ab}$ & $52.9 \mathrm{ab}$ & $53.0 \mathrm{fg}$ \\
\hline & 6.4 & $34.8 \mathrm{c}$ & $37.5 \mathrm{c}$ & $42.7 \mathrm{bc}$ & $38.3 \mathrm{~g}$ & $18.4 \mathrm{~b}$ & $48.3 \mathrm{ab}$ & $54.5 \mathrm{ab}$ & $40.4 \mathrm{~g}$ \\
\hline & Mean & $50.7 \mathrm{~h}$ & $50.7 \mathrm{~h}$ & $56.1 \mathrm{~h}$ & & $48.6 \mathrm{~h}$ & $50.6 \mathrm{~h}$ & $58.4 \mathrm{~h}$ & \\
\hline \multirow[t]{5}{*}{ Lesions per fruit } & Control & 46.5 & 36.1 & 24.8 & 34.6 & 140.0 & 87.6 & 70.0 & 95.0 \\
\hline & 3.2 & $8.6 \mathrm{abc}$ & $7.2 \mathrm{abc}$ & $8.6 \mathrm{abc}$ & $8.1 \mathrm{f}$ & $9.1 \mathrm{a}$ & $10.2 \mathrm{a}$ & $15.1 \mathrm{a}$ & $11.2 \mathrm{f}$ \\
\hline & 4.8 & $9.3 \mathrm{ab}$ & $12.5 \mathrm{a}$ & $10.9 \mathrm{a}$ & $10.8 \mathrm{f}$ & $9.6 \mathrm{a}$ & $7.0 \mathrm{a}$ & $9.6 \mathrm{a}$ & $8.6 \mathrm{f}$ \\
\hline & 6.4 & $2.7 \mathrm{~d}$ & $4.0 \mathrm{~cd}$ & $4.2 \mathrm{bcd}$ & $3.6 \mathrm{~g}$ & $16.7 \mathrm{a}$ & $6.5 \mathrm{a}$ & $8.9 \mathrm{a}$ & $9.9 \mathrm{f}$ \\
\hline & Mean & $6.0 \mathrm{~h}$ & $7.1 \mathrm{~h}$ & $7.3 \mathrm{~h}$ & & $11.4 \mathrm{~h}$ & $7.7 \mathrm{~h}$ & $10.9 \mathrm{~h}$ & \\
\hline \multirow[t]{5}{*}{ Lesions per infected fruit } & Control & 52.6 & 40.0 & 30.5 & 40.0 & 157.9 & 101.1 & 80.6 & 108.8 \\
\hline & 3.2 & $16.2 \mathrm{abcd}$ & $13.5 \mathrm{abcd}$ & $14.6 \mathrm{abcd}$ & $14.8 \mathrm{~g}$ & $16.5 \mathrm{a}$ & 20.9 a & $24.0 \mathrm{a}$ & $20.2 \mathrm{f}$ \\
\hline & 4.8 & $18.5 \mathrm{abc}$ & $23.6 \mathrm{a}$ & $20.4 \mathrm{ab}$ & $20.7 \mathrm{f}$ & $17.3 \mathrm{a}$ & $17.0 \mathrm{a}$ & $18.2 \mathrm{a}$ & $17.5 \mathrm{f}$ \\
\hline & 6.4 & $9.5 \mathrm{~d}$ & $11.9 \mathrm{bcd}$ & $10.5 \mathrm{~cd}$ & $10.6 \mathrm{~h}$ & $29.9 \mathrm{a}$ & $16.4 \mathrm{a}$ & $17.7 \mathrm{a}$ & $20.5 \mathrm{f}$ \\
\hline & Mean & $14.2 \mathrm{z}$ & $15.6 \mathrm{~h}$ & $14.6 \mathrm{~h}$ & & $20.4 \mathrm{~h}$ & $18.0 \mathrm{~h}$ & $19.8 \mathrm{~h}$ & \\
\hline
\end{tabular}

x Tukey's separations of least square means (natural log back transformed values, except incidence, which was not transformed) are presented $(\alpha=0.05)$.

y Different letters in each main effect or interaction group indicate significant differences among those means.

${ }^{\mathrm{z}} \mathrm{F}$ and $P$ values for the main effects and interactions are presented in Supplementary Table S3.
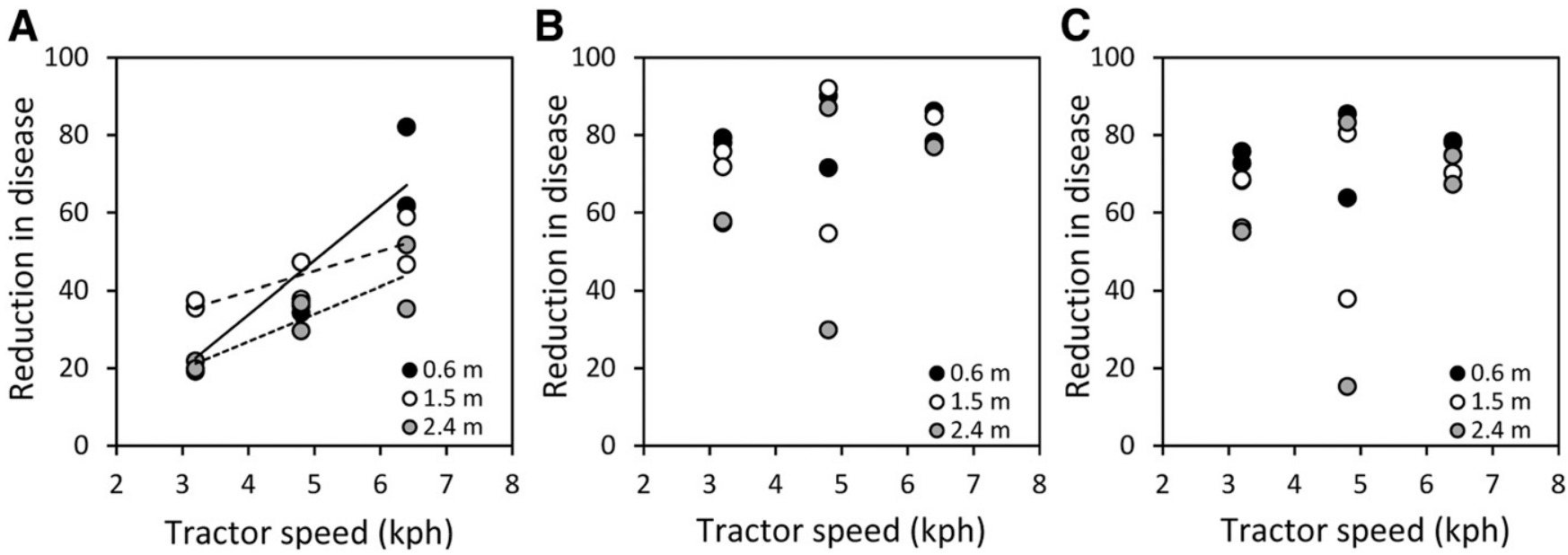

Fig. 3. The relationship between percent disease control and tractor speed at different sample heights for fruit infected with scab caused by Venturia carpophila in 2015 and 2016 (data from a particular height for each year at each speed have the same colored markers). A, incidence of infected fruit; $\mathbf{B}$, lesions per fruit; $\mathbf{C}$, lesions per infected fruit, respectively. Linear regression solutions are indicated where significant (for incidence at $0.6 \mathrm{~m}, \mathrm{~F}=12.6, P=0.02 ; \mathrm{y}=-21.7+13.8 \mathrm{x} ; \mathrm{R}^{2}=0.76 ;$ at $1.5 \mathrm{~m}, \mathrm{~F}=8.4, P=0.04 ; \mathrm{y}=19.4+5.11 \mathrm{x}$; $\mathrm{R}^{2}=0.68 ;$ at $2.4 \mathrm{~m}, \mathrm{~F}=12.6, P=0.02 ; \mathrm{y}=-1.4+7.07 \mathrm{x} ; \mathrm{R}^{2}=0.76$. 
cases (2015) slightly lower at $6.4 \mathrm{kph}$ compared with the other speeds. The results from our study suggest that the speed/volume/dose combination affects spray deposition in a way that most readily affected incidence of peach scab, while having less effect on the severity of peach scab on diseased fruit. We cannot explain this observation, but if explored further and understood, it may have value as a management tool. Without regard, increased tractor speed did not result in more disease. Increased tractor speeds mean that more orchard area can be covered in the same time and with less total spray volume per ha, potentially resulting in significant economic savings.

Fungicide applied at all tractor speeds significantly reduced peach scab at all heights compared with the control (data not shown). The treatment $\times$ sample height interaction is important to understand, as it can indicate where in the canopy disease control may be deficient. Also, peach fruit quality and yield distribution can be affected by tree pruning and training management (Caruso et al. 1998; Farina et al. 2005), thereby impacting the proportion of fruit that may benefit most from a variably deposited spray. Nonetheless, the main effects of tractor speed are probably most important to the producer (i.e., which treatments result in the lowest incidence and severity of scab?). Height effect differences were mostly numeric and generally small among treated peach trees - there was no obvious gradient of peach scab on fruit as has been described for other, larger tree crops that are sprayed with fungicides using airblast sprayers (Bock et al. 2017). The nontreated control peach trees generally showed a gradient in both scab incidence and severity: there was a higher incidence and more severe peach scab lower in the canopy (it was most pronounced for severity). In relation to sources of inoculum, this makes sense. Lan and Scherm (2003) demonstrated the splash dispersed nature of conidia of $V$. carpophila and the time of year when these conidia are produced (Scherm et al. 2008). Under gravity, the splash from sources of inoculum higher in the canopy will increase at lower points in the tree canopy so those fruit will be subject to more conidia-laden droplets, likely resulting in the more severe scab observed lower in the canopy. Conditions are likely to be more conducive to development of scab lower in the canopy, with more prolonged surface wetness (Lan and Scherm 2003). A similar gradient of more severe disease lower in the canopy has been noted in nonfungicide treated pecan trees (Bock et al. 2013).

At 701 liters/ha (6.4 kph), spray deposition is lower, but the concentration of Bravo is higher per spray droplet. Theoretically, the resulting greater quantity of a.i. per unit area provides a benefit to reducing the incidence of peach scab that we observed. Some redistribution of a.i. may occur subsequent to application due to rain and/or dew events. There is a risk of less good coverage at lower volumes/higher speeds, especially as trees leaf out. The deposition of spray in this study declined dramatically with canopy development. Although this may not be an issue for management of peach scab, it could impact management of other pests and diseases that are controlled by sprays later in the season. More foliage should allow a greater proportion of spray to adhere to the canopy, so if the increased foliage helps retain spray droplets to the levels seen in this study, lower volumes may still have advantages in some pest and disease situations. Application of a higher concentration spray and possibly a lower fan speed early in the season (low density peach foliage) will be less likely to force spray through the open canopy, increasing the quantity of a.i. available on the existing peach tree surfaces; it may still be necessary to increase spray volume and fan speed later in the season to obtain sufficient deposition throughout a fully developed peach canopy (high density peach foliage). The results of this study indicate that there may be benefits to lower volumes/higher tractor speeds for applying equivalent doses of fungicides to manage scab on peach. There are also benefits in task efficiency.

\section{Acknowledgments}

At USDA-ARS we acknowledge the technical help of Minling Zhang, Wanda Evans, Kaylee Carson, Sue Burrell, Gary Burnham, and Jason Shipp.

\section{Literature Cited}

Anonymous. 2004. United States Standards for grades of peaches. U.S. Department of Agriculture, Agricultural Marketing Service, Fruit and Vegetable Division,
Fresh Products Branch, Washington D.C. https://www.ams.usda.gov/sites/ default/files/media/Peach_Standard\%5B1\%5D.pdf

Banaj, D., Tadic, V., Lukinac, J., and Horvat, D. 2010. The use of water sensitive paper for the evaluation of spray coverage in an apple orchard. Poljoprivreda (Osijek) 16:43-49.

Barber, J. A. S., and Landers, A. J. 2002. The pros and cons of volume and rate reduction in orchard spraying. Paper number 021022, 2002 ASAE Annual Meeting.

Blaauw, B., Brannen, P., Lockwood, D., and Ritchie, D. 2019. Southeastern peach, nectarine, and plum pest management and culture guide. University of Georgia Extension Guide. Bulletin 1171

Bock, C. H., Cottrell, T. E., Hotchkiss, M. W., and Wood, B. W. 2013. Vertical distribution of scab in large pecan trees. Plant Dis. 97:626-634.

Bock, C. H., Hotchkiss, M. W., Brenneman, T. B., Stevenson, K. L., Goff, W. D., Smith, M. W., Wells, L., and Wood, B. W. 2017. Severity of scab and its effect on fruit weight in mechanically hedge-pruned and topped pecan trees. Plant Dis. 101:785-793.

Bock, C. H., Hotchkiss, M. W., Cottrell, T. E., and Wood, B. W. 2015. The effect of sample height on spray coverage in mature pecan trees. Plant Dis. 99:916-925.

Bock, C. H., Hotchkiss, M. W., Okie, W. R., and Wood, B. W. 2011. The distribution of peach scab lesions on the surface of diseased peaches. Eur. J. Plant Pathol. 130:393-402.

Caruso, T., Di Vaio, C., Inglese, P., and Pace, L. S. 1998. Crop load and fruit quality distribution within canopy of 'spring lady' peach trees trained to 'central leader' and 'y shape'. Acta Hortic. 465:621-628.

Celen, I. H., Arin, S., and Durgut, M. R. 2008. The effect of the air blast sprayer speed on the chemical distribution in vineyard. Pak. J. Biol. Sci. 11:1472-1476.

Chiba, M. 1974. Distribution of spray deposits in peach trees and number of leaves that constitute an adequate sample. J. Econ. Entomol. 67:529-534.

Cross, J. V., and Berrie, A. M. 1990. Efficacy of reduced volume and reduced dose rate spray programs in apple orchards. Crop Prot. 9:207-217.

Farina, V., Lo Bianco, R., and Paolo, I. 2005. Vertical distribution of crop load and fruit quality within vase- and Y-shaped canopies of 'Elegant Lady' peach. HortScience 40:587-591.

Fox, R. D., Brazee, R. D., Svensson, S. A., and Reichard, D. L. 1992. Air jet velocities from a cross-flow fan sprayer. Trans. ASAE 35:1381-1384.

Fox, R. D., Derksen, R. C., Krause, C. R., Cooper, J. A., and Ozkan, H. E. 2003. Visual and image system measurement of spray deposits using water-sensitive paper. Appl. Eng. Agric. 19:549-552.

Fox, R. D., Derksen, R. C., Zhu, H., Brazee, R. D., and Svensson, S. A. 2008. A history of air-blast sprayer development and future prospects. Trans. Am. Soc. Agric. Biol. Eng. 51:405-410.

Gil, E., Landers, A., Gallart, M., and Llorens, J. 2013. Development of two portable patternators to improve drift control and operator training in the operation of vineyard sprayers. Span. J. Agric. Res. 11:615-625.

Herrington, P. J., Mapother, H. R., and Stringer, A. 1981. Spray retention and distribution on apple trees. Pestic. Sci. 12:515-520.

Holownicki, R., Doruchowski, G., Godyn, A., and Swiechowski, W. 2000. PA-Precision agriculture: Variation of spray deposit and loss with air-jet directions applied in orchards. J. Agric. Eng. Res. 77:129-136.

Keitt, G. W. 1917. Peach scab and its control. United States Department of Agriculture Bulletin 395.

Lan, Z., and Scherm, H. 2003. Moisture sources in relation to conidial dissemination and infection by Cladosporium carpophilum within peach canopies. Phytopathology 93:1581-1586.

Lan, Z., Scherm, H., and Horton, D. L. 2003. Reduced midseason pesticide program for control for scab and plum curculio in peach. Plant Dis. 87:699-706.

Lawrence, E. G., Jr., and Zehr, E. I. 1982. Environmental effects on the development and dissemination of Cladosporium carpophilum on peach. Phytopathology 72:773-776.

Liu, H., Zhu, H., Chen, Y., Shen, Y., and Ozkan, H. E. 2013. Influence of travel speed on spray deposition uniformity from an air-assisted variable-rate sprayer. ASABE paper number 131594610, Kansas City, Missouri, July 21 July 24, 2013. http://dx.doi.org/10.13031/aim.20131594610.

Lombardo, V. A., Osorio, S., Borsani, J., Lauxmann, M. A., Bustamante, C. A., Budde, C. O., Andreo, C. S., Lara, M. V., Fernie, A. R., and Drincovich, M. F. 2011. Metabolic profiling during peach fruit development and ripening reveals the metabolic networks that underpin each developmental stage. Plant Physiol. 157:1696-1710.

Marucco, P., Tamagnone, M., and Balsari, P. 2008. Study of air velocity adjustment to maximise spray deposition in peach orchards. Agricultural Engineering International: the CIGR Ejournal: Manuscript ALNARP 08 009. Vol. X, May 2008.

Pergher, G. 2004. Field evaluation of a calibration method for air-assisted sprayers involving the use of a vertical patternator. Crop Prot. 23:437-446.

Randall, J. M. 1971. The relationships between air volume and pressure on spray distribution in fruit trees. J. Agric. Eng. Res. 16:1-31.

Reichard, D. L., Fox, R. D., Brazee, R. D., and Hall, F. R. 1979. Air velocities delivered by orchard air sprayers. Transactions of the ASAE, Paper No. 77 1037. 22:0069-0075.

Reilly, C. C., Wood, B. W., Cottrell, T. E., Sumner, P., Wells, L., and Funderburk, F. 2007. Comparison of ground and aerial application, fungicide deposition and biological activity in large pecan trees. Pages 115-122 in: Proc. Southeastern Pecan Growers Assoc., 100th Annual Convention, Marriot Bay Point Resort, Panama City Beach, Florida. 
Reilly, C. C., Taylor, K. C., and Hotchkiss, M. W. 2004. A comparison of air-blast and air assisted rotary atomizer spray technologies in peach production. HortTech. 14:555-559.

Rüegg, J., and Viret, O. 1999. Determination of tree row volume in stone-fruit orchards as a tool for adapting spray dosage. Bull. OEPP/EPPO Bull. 29:95-101.

Salyani, M., and Fox, R. D. 1999. Evaluation of spray quality by oil and water sensitive papers. Transactions of the ASAE, Paper No. 97-1049, 42:37-43.

Salyani, M., and Hoffmann, W. C. 1996. Air and spray distribution from an aircarrier sprayer. Appl. Eng. Agric. 12:539-545.

Salyani, M., Sweeb, R. D., and Farooq, M. 2006. Comparison of string and ribbon samplers in orchard spray applications. Trans. ASAE 49:1705-1710.

Salyani, M., and Whitney, J. D. 1990. Ground speed effect on spray deposition inside citrus trees. Transactions of the ASAE, Paper No. 89-1048, 33:0361-0366.

Scapin, M. S., Behlau, F., Scandelai, L. H. M., Fernandes, R. S., Silva, G. J., Junior., and Ramos, H. H. 2015. Tree-row-volume-based sprays of copper bactericide for control of citrus canker. Crop Prot. 77:119-126.

Scherm, H., and Brannen, P. M. 2005. Peach Scab. Pages 134-136 in: Southeastern Peach growers' Handbook. D. Horton and D. Johnson, eds. University of Georgia, College of Agricultural and Environmental Sciences, Athens, GA.

Scherm, H., and Savelle, A. T. 2001. Control of peach scab with reduced midseason fungicide programs. Plant Dis. 85:706-712.

Scherm, H., Savelle, A. T., Boozer, R. T., and Foshee, W. G. 2008. Seasonal dynamics of conidial production potential of Fusicladium carpophilum in southeastern peach orchards. Plant Dis. 92:47-50.

Schnabel, G., Layne, D., and Holb, I. 2007. Micronised and non-micronised sulphur applications control peach scab equally well with negligible differences in fruit quality. Ann. Appl. Biol. 150:131-139.
Schnabel, G., and Layne, D. R. 2004. Comparison of reduced-application and sulfur based fungicide programs on scab intensity, fruit quality, and cost of disease control on peach. Plant Dis. 88:162-166.

Sumner, P. E. 2004. Experiences with pecan air blast sprayers. Paper no. 041089 Presented at The 2004 American Society of Agricultural Engineers/Canadian Society of Agricultural Engineers Annual International Meeting, Fairmont Chateau Laurier, The Westin, Government Centre, Ottawa, Ontario, Canada, 1 4 August 2004. https://elibrary.asabe.org/azdez.asp?JID=5\&AID=17059\&CID= can $2004 \& v=\& i=\& T=1 \&$ refer $=7 \&$ access $=\& d a b s=Y$

Sutton, T. B., and Unrath, C. R. 1984. Evaluation of the tree-row-volume concept with density adjuvants in relation to spray deposit in apples orchards. Plant Dis. 68:480-484.

Sutton, T. B., and Unrath, C. R. 1988. Evaluation of the tree-row-volume model for full season pesticide application on apples. Plant Dis. 72:629-632.

Syngenta. 2002. Water-sensitive paper for monitoring spray distributions. Syngenta Crop Protection AG, Basel. TN08-223.

Travis, J. W., Skroch, W. A., and Sutton, T. B. 1987a. Effect of canopy density on pesticide deposition and distribution in apple trees. Plant Dis. 71:613-615.

Travis, J. W., Skroch, W. A., and Sutton, T. B. 1987b. Effects of travel speed, application volume, and nozzle arrangement on deposition of pesticides in apple trees. Plant Dis. 71:606-612.

Wicks, T. J., and Nitschke, L. F. 1986. Control of apple diseases and pests with low spray volumes and reduced chemical rates. Crop Prot. 5:283-287.

Wise, J. C., Jenkins, P. E., Schilder, A. M. C., Vandervoort, C., and Isaacs, R. 2010. Sprayer type and water volume influence pesticide deposition and control of insect pests and diseases in juice grapes. Crop Prot. 29:378-385.

Yates, W. E., Ogawa, J. M., and Akeson, N. B. 1974. Spray distribution in peach orchards from helicopter and ground applications. Transactions of the ASAE, Paper No. 68-617, 16:633-644. 